The Practice of Citizenship 
This page intentionally left blank 


\title{
THE PRACTICE \\ OF CITIZENSHIP
}

Black Politics and Print Culture in the Early United States

\section{Derrick R. Spires}

\author{
$\overline{\text { PENN }}$ \\ UNIVERSITY OF PENNSYLVANIA PRESS \\ PHIL A DEL P H I A
}


Copyright (C) 2019 University of Pennsylvania Press

All rights reserved.

Except for brief quotations used for purposes of review or scholarly citation, none of this book may be reproduced in any form by any means without written permission from the publisher.

\author{
Published by \\ University of Pennsylvania Press \\ Philadelphia, Pennsylvania 19104-4112 \\ www.upenn.edu/pennpress \\ Printed in the United States of America \\ on acid-free paper \\ 13579108642 \\ Library of Congress Cataloging-in-Publication Data \\ ISBN 978-0-8122-5080-0
}


For Daisy and Nafissa 
This page intentionally left blank 